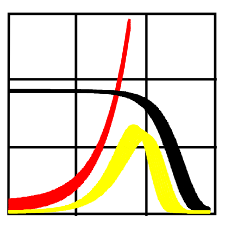

Max-Planck-Institut für demografische Forschung

Max Planck Institute for Demographic Research

Doberaner Strasse 114 - D-18057 Rostock · GERMANY

Tel +49 (0) 3812081 - 0; Fax +49 (0) 3812081 - 202;

http://www.demogr.mpg.de

MPIDR WORKING PAPER WP 2000-004

MARCH 2000 (Revised 30 August 2000)

Employment Careers and the

Timing of First Births in East Germany

Michaela Kreyenfeld (Kreyenfeld@demogr.mpg.de)

This working paper has been approved for release by: Hans-Peter Kohler (kohler@ demogr.mpg.de) Head of the Research Group on Social Dynamics and Fertility

(C) Copyright is held by the authors.

Working papers of the Max Planck Institute for Demographic Research receive only limited review. Views or opinions expressed in working papers are attributable to the authors and do not necessarily reflect those of the Institute. 


\title{
Employment Careers and the Timing of First Birth in East Germany
}

\author{
Michaela Kreyenfeld *)
}

\begin{abstract}
:
When German unification was accompanied by a rapid decline in aggregate fertility rates, researchers particularly assigned high unemployment rates a dominant role for changes in fertility behavior. The aim of this paper is twofold. First, we investigate changes in the timing of first birth in East Germany after unification. Using data from the SOEP, we show that even after unification East Germans are younger at first birth than their West German counterparts. Second, we investigate the relationship between male and female unemployment and first birth risks. A major result is that female unemployment fosters the transition into parenthood in East Germany.
\end{abstract}

JEL-Classification: J13, J22

*) The author would like to thank Francesco Billari, Karl Brehmer, Tomas Frejka, Jan Hoem, Johannes Huinink and Hans-Peter Kohler. The view expressed in this paper is my own. It does not necessarily reflect the view of the Max Planck Institute for Demographic Research. 


\section{Introduction}

The fall of the Berlin Wall on November 9th, 1989 is usually equated with the breakdown of the GDR regime. Monetary union with West Germany followed in July and German unification in October 1990. As can be seen from Figure 1, aggregate fertility rates in East Germany declined almost immediately after German unification. While there were still 180,000 births in 1990 , there were only 110,000 a year later. This is a drop in the number of births by about 40 percent over the period of a single year. The TFR, which is a more accurate account of the population at risk of childbirth, displays a similar pattern. The TFR in East Germany dropped from 1.5 in 1990 to 1.0 in 1991 , reaching its lowest level of 0.8 in the years 1992 to 1995.

\section{[Figure 1 about here]}

The decline in birth rates has caused an extensive discussion about the determinants of these rapid and drastic changes. The hypothesis that is possibly discussed most often is the idea of a "crisis phenomenon." Eberstadt (1994: 150) views the East German fertility decline as a "demographic shock". He argues that fertility rates in East Germany "register a profound and broadly felt lack of confidence in the economic future." In a similar fashion, Fleischhacker (1994: 43) describes fertility decline after unification as the result of a severe economic crisis comparable to the post-war periods. Witte and Wagner

There are certainly other aspects, which are also discussed in this context. The most often cited reasons for an early first birth in former East Germany are presumably East German housing policies, the East German 'marriage loan', the public provision with day care, generous leaves for mothers with sick children etc. (for a detailed overview, see Cromm 1998). Schaich (1998) relates low East German birth rates to an increase in consumption opportunities after unification. Other authors observe a loss of a "family orientated life 
(1995: 395) do not speak of a shock experience, but they still argue that "there is no reason to expect the total fertility rate in the East to rebound to the level found in the West." Unfavorable labor market constraints, i.e. high unemployment rates, are expected to keep East Germany's fertility rate below West German levels.

\section{Timing or Quantum?}

One of the most striking feature of the discussion about the "East German fertility crisis" is that it concentrates largely on finding an explanation for a "fertility decline", generally using the annual TFR as an indicator. ${ }^{2}$ Among demographers it is well known that the (commonly used) TFR is severely subject to misinterpretation (Bongaarts/ Feeney 1998). It not only fails to differentiate between births of different orders but, most importantly, it obscures the difference between "tempo" and "quantum effects" of fertility. A decline in the TFR might indeed be related to a decline in life-time fertility, but it might just as well be related to a postponement of motherhood.

Compared to other European countries, the mean age at childbirth was relatively low in East Germany. In 1989, the mean age at childbirth was 24.7 (for first births: age 22.7, for second births: 26.3) (Bundesinstitut für Bevölkerungswissenschaft 1999). Then there is West Germany, which displays a rather high age at childbirth in a cross-national comparison. In 1989, the mean age at childbirth in West Germany was 28.3 for all

style" and an emergence of a "post modern" family structure (see e.g., Beck-Gernsheim 1997).

2 It should be noted that there are several authors who argue that changes in the timing of first birth might be an important factor in the drop in the TFR after unification (e.g. Conrad/ Lechner/ Werner 1996: 339, Dorbritz 1997: 239, Schultz/ Wagner/ Witte 1993: 13). However, to our knowledge, there is little empirical research on changes in the timing of first birth after unification. An exception is e.g. the study by Sackmann (1999). His analysis is however restricted to a sample of East Germans from Rostock and Leipzig who have a vocational training certificate or a college degree. 
parities (Statistisches Bundesamt 1999). The considerable difference in the age at childbirth between East and West Germans is rather crucial for understanding an "East German fertility decline". Even if East Germans temporarily gave up on child bearing during the upheavals of German unification, East German women were still young enough to postpone childbearing easily to a later phase in their lives without reaching social and biological limits of fertility (or West German levels).

One of the most interesting questions might therefore be whether the decline in the TFR indeed indicates "quantum effects" or if it is related instead to a postponement of childbirth in the individual life course. A simple method to detect changes in the timing of parenthood is the use of cohort fertility rates. However, German vital statistics only provide births by orders in the current marital union. With almost half of all births being out-of wedlock in East Germany, vital statistics are of limited value when analyzing changes in the timing of childbirth in East Germany after unification (Statistisches Bundesamt 1999). The aim of this paper is twofold. First, we use survey data to describe the timing of first births for different East German birth cohorts before and after unification. Second, we investigate whether the negative correlation between high unemployment and low fertility rates also holds true on the micro level. In other words: Does unemployment induce a postponement of first birth in East Germany?

This paper is structured in the following manner. In the first part, we discuss some general features of the East German labor market before and after unification. In the second part, we discuss the general framework that relates female and male unemployment and child timing decisions. The third part comprises the empirical analysis. This part consists of two sections. In the first section, we simply describe the timing of first birth of different East German birth cohorts before and after German unification (using simple Kaplan-Meier survival curves). The second section comprises 
the multivariate analysis, where we analyze the impact of male and female unemployment on first birth risks in East German after German unification (using an event history model).

\section{The East German Labor Market}

It is often believed that there is no real dichotomy between a "free market system" on the one hand and a centrally planned economy on the other (Szydlik 1994: 200). Government intervention is prevalent in any society. Conversely, there is also room for a free choice in a centrally planned economy. Nevertheless, it is indisputable that in a centrally planned economy like former East Germany, government intervention was rather encompassing. The production of goods and services was largely governed by the 'plan'. Firms were mostly publicly owned, wages and prices were centrally set. Labor market mobility was severely restricted, i.e. upward mobility was very much constrained by predetermined career paths, internal labor market restricted job mobility and the statuary right to work insured against unemployment (Solga/ Konietzka 1999, Grünert/ Karl 1997, Sackmann/ Wingens 1996).

With German unification, the set-up of the East German labor market drastically changed. In the subsequent years, East Germans witnessed a thorough "restructuring" of the labor market, i.e. closures of firms and with it dismissals of workers on a large scale. This means that East Germans not only lost the predictability of their career paths that they were used to from former East Germany. Furthermore, they were even at greater risk of experiencing unemployment, change of jobs or unstable employment conditions than their West German counterparts. Empirical analysis reveals that almost half of all East 
Germans males experienced some time of unemployment or some time of job creation programs in the immediate period after unification (Bielinski/ Brinkmann/ Kohler 1995). Panel 1 in Figure 2 displays male unemployment rates for the period 1990 to 1999 in East and West Germany. In 1990, unemployment rates were on a still moderate level in East Germany. However, with the cut back of job creation programs, unemployment rates increased well above West German levels in the subsequent years.

\section{[Figure 2 about here]}

Concerning female employment, there is consistent empirical evidence that the restructuring of the East German labor market has particularly "disrupted" the working careers of women. East German women were at a higher risk of unemployment and they had lower chances of returning to the labor market after being unemployed than their male counterparts (e.g., Diewald/ Mayer/ Solga 1999, Engelbrech/ Reinberg 1997, Holst/ Schupp 1995). Similar to their male counterparts, women without formal qualifications were the ones most likely being subject to unemployment. In 1995, about half of all East German women without any formal qualifications were unemployed, while on the other hand there was only little unemployment (about 5 percent) among East German women with a college degree. Engelbrech and Reinberg (1997: 11) even speak of a polarization among East German women, with highly qualified employed women on the one hand, and not working women without sufficient formal qualifications on the other. 


\section{Theoretical Considerations}

From the perspective of neoclassical theory, there are at least two factors relating fertility and employment. First, children are expected to cost a substantial amount of money, which is generally acquired through participating in the labor market (Turchi 1975). Second, rearing children is a time-intensive activity, which therefore competes with time one could otherwise spend in gainful employment (Becker 1993, Hirschman 1994). If one assumes the traditional division of labor in the household (i.e., the man is responsible for providing for the family and the woman for child-rearing) this yields two straightforward hypotheses on the relationship between unemployment and fertility. On the one hand, male unemployment should have a postponing effect on childbirth. In times of unemployment the male "bread-winner" is hardly able to support a family and the couple should therefore postpone parenthood until the husband has returned to gainful employment. Female unemployment, on the other hand, should encourage couples to have children. Female unemployment reduces the time costs of having children, which makes it reasonable for a woman to give birth when she experiences unemployment (Butz/ Ward 1979, Zimmerman/ DeNew 1990).

\section{Career Planning and Fertility}

One might argue that the standard neoclassic framework is rather myopic in that it does take into consideration the fact that the decision to have a child involves a longer time perspective. During times of unemployment, the opportunity costs of having children are low. However, childbirth usually requires a longer time of absence from the labor market than a woman would have otherwise spent unemployed. Most importantly, fertility decisions and childbirth are separated by nine months. Furthermore, a mother is not able 
to return to the labor market immediately after giving birth to a child. In Germany, mothers are prohibited from working during the first eight weeks after childbirth. In addition, when the child is still very young parents might be less willing to put their children in day care. The longer a woman withdraws from the labor market after childbirth, however, the greater her chances of experiencing a devaluation of her human capital and the lower her chances of a smooth return to the labor market. In other words, if a woman decides to have a child while being unemployed, she will most likely withdraw from the labor market substantially longer than the period of unemployment would normally have lasted. It is most likely that she will experience a devaluation of her human capital, which will reduce her chances of resuming employment.

If, on the other hand, a woman decides to have a child while she is in regular employment, she has a far better chance of returning to the labor market after childbirth. In Germany, a woman who is employed before the birth of her child is entitled to take advantage of maternity leave regulations, which entail the guaranteed right to return to her job up to three years after the birth of a child. Given this institutional setting, one would expect women to first search for a stable employment situation, which then facilitates a smooth return to their previous employment after childbirth. From this perspective, female unemployment should have a postponing effect on a first birth (see e.g., Adler 1997).

\section{Labor Market Discouragement and Fertility}

The line of reasoning sketched above assumes that unemployment has a postponing effect on childbirth due to a woman's career-planning motives. It implicitly assumes that women have a desire to bring their employment and fertility "careers" into synch with 
each other. Friedman, Hechter and Kanazawa (1994: 382ff.) challenge this line of reasoning with a set of rather provocative hypotheses. They basically argue that, in contemporary societies, women face a choice between an employment career and a "career" as mother and housewife. Although women might wish to pursue an employment career, bleak employment prospects might discourage them from doing so. Women then respond to their unfavorable employment prospects by choosing the secure and predictable career of a mother and housewife instead. Similarly to the standard neoclassic framework, female unemployment has an accelerating impact on childbirth in this framework. However, the choice to have a child is not a short-term decision influenced solely by the opportunity costs of child-rearing. Rather, it is a long-term decision which encompasses the future employment situation.

\section{Unemployment and Fertility in East Germany}

To summarize our line of thought: the neoclassic framework postulates a negative correlation between male unemployment and fertility and a positive one for female unemployment and fertility. In the case of female unemployment, we have characterized the standard neoclassic framework as rather myopic, because it does not take into account the long-term costs of opting for parenthood when a woman experiences unemployment. We have argued that one would rather expect a woman to first search for a stable employment situation before she opts for parenthood. This assures her the right to return smoothly to her job after childbirth, thus guaranteeing a continuous employment career. This line of argument takes for granted, however, that East German women seek an employment career. In principle, this fits the East German situation very well. East German women are often described as being more attached to an employment career than 
their West German counterparts (Trappe 1995). When they become unemployed, they are more active in seeking new employment. If they are working part-time, they express a greater desire to work full-time (e.g. Holst/ Schupp 1996). This high level of "labor market attachment" on the part of most East German women is severely constrained, however, by rather discouraging labor market constraints, e.g., high female unemployment rates, low chances of entering the labor market once unemployed, high risks of downward status mobility after unemployment. In line with Friedman, Hechter and Kanazawa (1994), one might interpret a negative impact of female unemployment on fertility as a "labor market discouragement" of unemployed East German women.

\section{Empirical Analysis}

The empirical analysis consists of two parts. First, we describe the timing of first birth in East Germany before and after unification, using simple Kaplan-Meier survival curves. Second, we analyze the impact of male and female unemployment on first birth risks after German unification, using a piecewise constant model (see e.g. Blossfeld/ Rohwer 1988). As a data source, we are using the German Socio-Economic Panel (SOEP) of the year 1998. The analysis is restricted to East and West Germans of the birth cohorts 1955 to 1980. To reduce the heterogeneity of the comparison group, foreign nationals are excluded. Furthermore, individuals with missing information on the key variable (i.e. the birth biography) are also omitted. ${ }^{3}$ Altogether, the sample comprises 1,367 East German

For readers who are familiar with the structure of the SOEP: We only use sample A and C. Furthermore, we exclude all (other) foreigners and ethnic German migrants from the analysis. We only use women who realized at least one interview. Finally, we omit all 
women, who gave birth to 780 children before censoring (and 2,536 West German women who gave birth to 1,086 children).

\section{Description of Survival Curves}

In Figure 3 (Panel 1), the survival curve for the transition to first birth for the birth cohorts 1955-1960 is displayed. The date of censoring is the beginning of the year 1991 . As expected, the mean duration until first birth is significantly lower in the German Democratic Republic (GDR). At the age of 22, about 50 percent of all East German women have already had a first birth. In West Germany, the median duration is more than five years higher.

\section{[Figure 3 about here]}

The crucial question is how East Germans changed their timing of the first birth after German unification. For descriptive purposes, we make a distinction by "Pre-Unification Cohorts", "Unification Cohorts" and "Post-Unification Cohorts". "Pre-Unification Cohorts" (1955-60) almost exclusively gave birth before unification. The "Unification Cohorts" (1961-1970) gave first birth before or after German unification. "PostUnification Cohorts" (1971-80) entered child-bearing age after 1990 (disregarding women who gave birth at age 18 or earlier). In Panel 2 of Figure 3, the survival curves for they gave birth before age 17 ( 8 cases). 
the different East German birth cohorts are displayed. The major findings from the survival curves can be summarized as follows:

-The "Post-Unification Cohorts" clearly display a different pattern in the transition to first birth compared to the "Pre-Unification Cohorts". The expected difference in the median duration time until first birth will amount to about four to five years between the two comparison groups. (We are unable to report a median duration time until first birth yet. If one compares, however, the age when 30 percent of the "Unification Cohorts" and the "Pre Unification Cohorts" had their first child, one observes a fiveyear age difference.)

- This poses the question, whether the "Post-Unification Cohorts" are displaying a similar timing pattern as their West German counterparts. A comparison with the same West German cohorts (Figure 4, Panel 1) does however not support this hypothesis. East Germans of the "Post Unification Cohorts" are still younger at first birth than comparable West German cohorts.

- Members of the "Unification Cohorts" (1961-1970) mostly gave first birth before German unification. However, those childless at the time of German unification are still younger at first birth in the subsequent years than their West German counterparts (Figure 4, Panel 2).

- In 1998 (respectively the date of censoring), about 80 percent of the East German "Unification Cohorts" already have their first child. Among the West Germans, this ratio amounts to around 60 percent (the West German curve is not displayed).

\section{[Figure 4 about here]}




\section{To summarize so far: Timing or Quantum?}

In the beginning of this paper, we have argued that the drop in the TFR in East Germany after unification is mostly interpreted in the sense that East Germans have ceased child bearing. Our results suggest that the fluctuations in the TFR after unification in East Germany will most likely be due to substantial changes in the age at childbirth. However, we are unable to thoroughly answer this question. First, we only address the transition to first birth in our analysis. Second, we are unable to ascertain the extent of "quantum effects" yet. Since we are dealing with first births, this is the ratio of childlessness. In former East Germany, the ratio of childlessness (measured at age 35) amounts to about 8 percent (Bundesinstitut für Bevölkerungswissenschaft 1999). In West Germany, the ratio of childlessness amounts to around 20 to 30 percent for birth cohorts born after 1955 (Dorbritz and Schwarz 1996: 234). Whether there will be an increase in childlessness compared to former East Germany can simply be not been assessed yet. East Germans of the "Unification Cohorts" have not reached the biological (and social) limits of fertility in 1998. However, a comparison of East and West German "Unification Cohorts" already reveals an important aspect. In 1998, there are 80 percent of the East German "Unification Cohorts" who already have a first birth. For their West German counterparts, this applies to only 60 percent. Considering further that the ratio of childlessness in West Germany will most likely surmount 20 percent, there is good reason to believe that the East German "Unification Cohorts" will eventually display a lower ratio of childlessness than their counterparts in the West. 


\section{Multivariate Analysis}

In the following, we address the question whether the correlation between unemployment and fertility we observe on the macro level also holds true on the micro level. In other words: Does unemployment have a postponing effect on first birth risks in East Germany after unification? As a method, we use a piecewise constant model. ${ }^{4}$ We exclude the period before unification, since unemployment did virtually not exist at that time yet. Furthermore, we simply do not have accurate information on the employment status of the East German sample for this time period. For this analysis, we only use East and West Germans of the birth cohorts 1961-1980. Altogether there are 687 East German women in the remaining sample, for which we observe 144 births (and 1,584 West German women with 331 births).

The dependent variable in this model is the age of a woman measured in months since the year she turned age 15. The major independent variable is the activity status of the woman and her partner. We make a distinction by (1) unemployment, (2) education, (3) full-time employment and (4) part-time employment. It should be noted that we use monthly information on the activity status of the woman, however, for the cohabiting partner we only have annual activity information at our disposal. It is clearly a drawback that we do not have monthly activity information of the male partner. On the other hand, using annual information, we are able to distinguish the employment status of the male partner in a more sophisticated manner. We distinguish (1) regular full-time employment, (2) unemployment, (3) education and (4) non-regular employment. The latter includes part-time employment, short work, temporary leave (Freistellung), marginal employment 
and term-limited working contracts (including job creation programs). Furthermore, we control for whether the male partner has changed jobs within the last year. Other controlling variables in the regression are: the educational status (distinguished by no degree, vocational degree and college degree as time-variant covariates) and a binary variable for whether the partner is living in the same household. To allow the covariates to have an impact on the decision to become pregnant, the date of birth is backdated by nine months.

We first estimate a simple model, where we solely control for the activity status of the woman. In the second model, we investigate more deeply into the impact of female unemployment on first birth risks. We use several specifications, i.e. we distinguish between short and long term unemployment (respectively more or less than three months of unemployment). Furthermore, we allow the activity status to have a different impact for women with and without formal educational qualifications. ${ }^{5}$ In the last model, we add on the partner's characteristics to the regression. The results are displayed in Table 1-3 in the Appendix. They can be summarized as follows:

- Female unemployment has a strong positive impact on first birth risks in East Germany. However, when one distinguishes between long (more than three months) and shortterm unemployment (three months and less), only the former retains a significant and strong effect.

$4 \quad$ We use the computer software Transition Data Analysis (TDA 6.3) (Rohwer/ Pötter 1999). To aggregate activity spells, we use the program NEWSPELL (version 1.2) (Pischner 2000).

5 For this analysis, we group part-time and full-time employment into one category. Furthermore, we group women with a vocational and a college degree into one category. Nevertheless, it should be noted that an interaction of the activity status and "no degree" produces rather sparse matrices. For the combination "unemployment" and "no degree", there are only 24 respondents (and 247 person months at risk). 
- Adding on the educational characteristics of the woman, the impact of unemployment almost vanishes. This suggests that the negative impact of unemployment is largely transmitted through educational attainment. An interaction of the unemployment variable with "no degree" reveals that only for women without any formal qualifications, unemployment has a strong positive impact on first birth risks.

- Male unemployment has a negative but insignificant impact on first birth risks after unification in East Germany. Other employment characteristics of the male partner (e.g. a change of job or a non-regular employment contract) have neither any sizeable impact.

\section{Concluding Remarks}

When German unification was accompanied by a rapid decline in aggregate birth rates, researchers particularly assigned high unemployment rates a dominant role for changes in fertility behavior. The aim of this paper was to highlight two aspects:

- First, we compared East and West German fertility patterns after unification using cohort data. From this perspective, the East German situation does not look like a "fertility crisis" at all. Compared to their West German counterparts, East Germans are still younger at first birth after unification.

- Second, the correlation of high unemployment rates and low fertility rates on the macro level does not necessarily transfer to the micro level. For female unemployment, we even find a strong positive impact on first birth risks. 
Thus, there are several restrictions to be named. We argue that the rapid decline in the TFR after unification will most likely relate to substantial changes in the timing of parenthood. The drastic increase in the age at first birth we observe in our analysis makes this reasoning very likely. This finding should, however, not play down the fact that the annual number of births in the period 1990-1995 is at alarming low levels in East Germany. This will certainly entail far-reaching consequences. One of the very immediate consequences that can already be witnessed are the cut backs in the social infrastructure (such as a downsizing in the slots in schools and in public day care). Furthermore, it should be noted that we solely focus on changes in the timing of first births in our study. An analysis of higher parity births is however constrained by insufficient sample sizes. It should also be noted that we are unable to assess quantum effects yet. Given that our data is censored in 1998, this is simply too early to estimate the final ratio of childlessness among the "Unification Cohorts". Nevertheless, comparing the ratio of childlessness among East and West Germans of the "Unification Cohorts" in the year 1998, there is good reason to believe that East German "Unification Cohorts" will eventually encounter a lower ratio of childlessness compared to their West German counterparts.

In the second part of the empirical analysis, we addressed the correlation between unemployment and the timing of childbirth in East Germany. One major aspect we highlighted in our analysis is that the macro correlation between high unemployment rates and low fertility rates which is observed in East Germany after unification (and also in other former communist country) does not necessarily transfer to the micro level. We do not find any sizeable impact of male unemployment on first birth risks in East Germany after unification. However, we cannot rule out that our results relate to the crude indicator we used for male employment. For females, where we had an accurate 
measure at our disposal, we find a strong accelerating impact of unemployment on first birth risks. If one distinguishes unemployment states further, we find that the positive impact of unemployment on first birth risks mainly holds for women who experience long-term unemployment and women who do not have any formal qualifications. Whether this can be interpreted as a labor market discouragement of East German women, who face small chances of succeeding in the labor market, certainly demands further investigations. 


\section{References}

Adler, M. A. (1997), Social change and decline in marriage and fertility in eastern

Germany. Journal of Marriage and the Family 59 (1): 37-49.

Beck-Gernsheim, E. (1997), Geburtenrückgang und Kinderwunsch - die Erfahrung in Ostdeutschland. Zeitschrift für Bevölkerungswissenschaft 22: 59-71.

Becker, G.S. (1993), A treatise on the family. Enlarged edition. Cambridge (Massachusetts).

Bundesinstitut für Bevölkerungswissenschaft (1999), Altersspezifische Geburtenziffern für Ostdeutschland für den Zeitraum 1952-1988. Wiesbaden. (provided by Jürgen Dorbritz).

Bielenski, H./ Brinkmann, C./ Kohler, B. (1995), Erwerbsverläufe seit der Wende in Ostdeutschland: Brüche und Kontinuitäten. IAB Werkstattbericht (6).

Blossfeld, H.P./ Rohwer, G. (1988), Techniques of Event History Analysis. Hillsdale.

Bongaarts, J./ Feeney, G. (1998), On the quantum and tempo of fertility. Population and Development Review 24 (2): 271-291.

Butz, W.P./ Ward, M.P. (1979), The emergence of countercyclical U.S. fertility. American Economic Review 69 (3): 318-328.

Conrad, C./ Lechner, M./ Werner, W. (1996), East German fertility after unification: crisis or adaptation? Population and Development Review 22 (2): 331-358. 
Cromm, J. (1998), Familienbildung in Deutschland: soziodemographische Prozesse,

Theorie, Recht und Politik unter besonderer Berücksichtigung der DDR. Opladen and Wiesbaden.

Diewald, M./ Mayer, K.U./ Solga, H. (1999), Transitions to post-communism in East Germany: Worklife mobility of woman and men between 1989 and 1993. Acta Sociologica 42 (1): 35-53.

Dorbritz, J. (1997), Der demographische Wandel in Ostdeutschland - Verläufe und Erklärungsansätze. Zeitschrift für Bevölkerungswissenschaft 22 (1): 239-268.

Dobritz, J./ Schwarz, K. (1996), Kinderlosigkeit in Deutschland - ein Massenphänomen? Analysen zur Erscheinungsformen und Ursachen. Zeitschrift für Bevölkerungswissenschaft (21) 3: 231-261.

Eberstadt, N. (1994), Demographic shocks after communism: Eastern Germany, 1989-93. Population and Development Review 20 (1): 137-151.

Engelbrech, G./ Reinberg, A. (1997), Frauen und Männer in der Beschäftigungskrise der 90er Jahre. IAB Werkstattbericht (11).

Fleischhacker, J. (1994), Im Westen stabil - im Osten instabil. Die ostdeutsche Bevölkerungsbewegung im Umbruch. Forum, demographie und politik (6): 31-52.

Friedman, D./ Hechter, M./ Kanazawa, S. (1994), A Theory of the Value of Children. Demography 31 (3): 375-401.

Grünert, H./ Karl, A. (1997), Beschäftigungssystem und Arbeitsmarkt in der DDR. Opladen. 
Hirschman, C. (1994), Why fertility changes. Annual Review of Sociology 20: 203-233.

Holst, E./ Schupp, J. (1995), Aspekte der Arbeitsmarktentwicklung in Ostdeutschland. DIW-Wochenbericht (23): 1-17.

Holst, E./ Schupp, J. (1996), Erwerbstätigkeit von Frauen in Ost- und Westdeutschland weiterhin von steigender Bedeutung. DIW-Wochenbericht (28): 461-469.

Kleinbaum, D.G. (1996), Survival Analyis. New York.

Pischner, R. (2000), Documentation of the Program Newspell (Version 1.2). In: SOEP 1984-1998. (CD-Rom).

Rohwer, G./ Pötter, U. (1999), TDA User’s Manual. Ruhr-Universität Bochum.

Sackmann, R. (1999), Ist ein Ende der Fertilitätskrise in Ostdeutschland absehbar? Zeitschrift für Bevölkerungswissenschaft 24 (2): 187-211.

Sackmann, R./ Wingens, M. (1996), Berufsverläufe im Transformationsprozeß. In: Diewald, M. (et al.) (eds.): Zwischenbilanz der Vereinigung. Opladen: 11-88.

Schaich, E. (1998), Der Geburteneinbruch in den neuen Bundesländern seit 1990 einige Hypothesen zu seiner Erklärung. Jahrbücher für Nationalökonomie und Statistik 217 (1): 93-107.

Schultz, E./ Wagner, G.G./ Witte, J.C. (1993), Gegenwärtiger Geburtenrückgang in Ostdeutschland läßt mittelfristig einen "Babyboom” erwarten. DIW Diskussionspapier (84).

Solga, H./ Konietzka, D. (1999), Occupational matching and social stratification. European Sociological Review 15 (1): 25-47. 
Statistisches Bundesamt (1999), Bevölkerung und Erwerbstätigkeit. Gebiet und Bevölkerung. Fachserie 1 Reihe 1. Wiesbaden.

Szydlik, M. (1994), Incomes in a planned and a market economy: the case of the German Democratic Republic and the 'former' Federal Republic of Germany. European Sociological Review (10) 3: 199-217.

Trappe, H. (1995), Emanzipation oder Zwang? Frauen in der DDR zwischen Beruf, Familie und Sozialpolitik. Berlin.

Turchi, B.A. (1975), The demand for children. The economics of fertility in the United States. Cambridge.

Witte, J.C./ Wagner, G.G. (1995), Declining fertility in East Germany after Unification: a demographic response to socioeconomic change. Population and Development Review 21 (2): 387-397.

Zimmermann, K. F./ DeNew, J. (1990), Arbeitslosigkeit und Fertilität. In: Felderer, B. (ed.): Bevölkerung und Wirtschaft. Berlin: 95-109. 


\section{Appendix}

Table 1: First Birth Risks in East and West Germany after Unification (Model I)

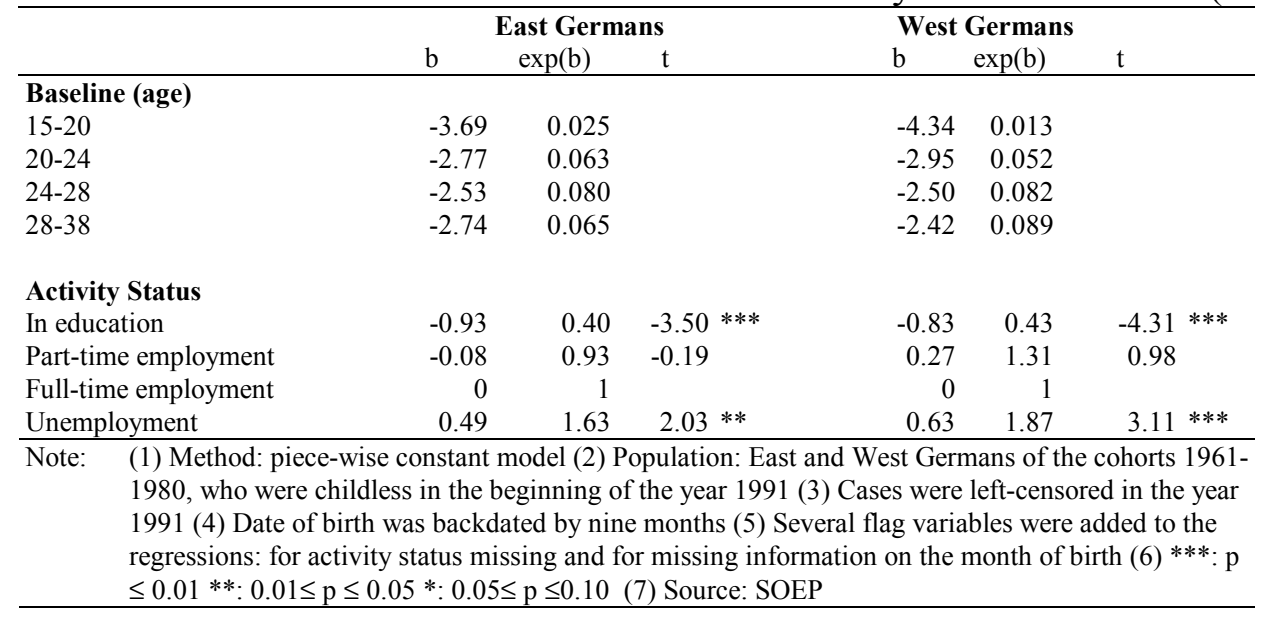

Table 2: First Birth Risks in East Germany after Unification (Model II)

\begin{tabular}{|c|c|c|c|c|c|c|c|c|c|}
\hline & $\mathrm{b}$ & $\exp (b)$ & $\mathrm{t}$ & $\mathrm{b}$ & $\exp (b)$ & $\mathrm{t}$ & $\mathrm{b}$ & $\exp (b)$ & $\mathrm{t}$ \\
\hline \multicolumn{10}{|l|}{ Baseline (age) } \\
\hline \multicolumn{10}{|l|}{$15-20$} \\
\hline $20-24$ & -3.69 & 0.025 & & -3.53 & 0.029 & & -3.99 & 0.02 & \\
\hline $24-28$ & -2.77 & 0.063 & & -2.62 & 0.072 & & -2.98 & 0.05 & \\
\hline \multirow[t]{2}{*}{$28-38$} & -2.54 & 0.079 & & -2.24 & 0.107 & & -2.64 & 0.07 & \\
\hline & -2.74 & 0.065 & & -2.55 & 0.078 & & -2.89 & 0.06 & \\
\hline \multicolumn{10}{|l|}{ Education } \\
\hline No Degree & -- & & & 1.17 & 3.23 & $4.31 * * *$ & -- & & \\
\hline Vocational Degree & -- & & & 0 & 1 & & -- & & \\
\hline College Degree & -- & & & 0.15 & 1.16 & 0.44 & -- & & \\
\hline \multicolumn{10}{|l|}{ Activity Status } \\
\hline In education & -0.93 & 0.40 & $-3.51 * * *$ & -0.87 & 0.42 & $-3.44 * * *$ & -- & & \\
\hline Part-time employment & -0.08 & 0.93 & -0.19 & -0.12 & 0.89 & -0.28 & -- & & \\
\hline Full-time employment & 0 & 1 & & 0 & 1 & & -- & & \\
\hline Unemployment & -- & & & 0.36 & 1.44 & 1.46 & -- & & \\
\hline Unemployment ( $\leq 3$ months) & 0.33 & 1.39 & 0.78 & -- & & & -- & & \\
\hline Unemployment ( $>3$ months) & 0.56 & 1.75 & $2.03 * *$ & -- & & & -- & & \\
\hline \multicolumn{10}{|l|}{ Activity Status \& Education } \\
\hline In Education & -- & & & -- & & & -0.81 & 0.45 & $-3.09 * * *$ \\
\hline Employment \& no degree & -- & & & -- & & & 0.83 & 2.30 & $1.78 *$ \\
\hline Employment \& degree & -- & & & -- & & & 0 & 1 & \\
\hline Unemployment \& no degree & -- & & & -- & & & 1.84 & 6.31 & $4.79 * * *$ \\
\hline Unemployment \& degree & -- & & & -- & & & 0.20 & 1.22 & 0.67 \\
\hline \multicolumn{10}{|c|}{$\begin{array}{l}\text { Note: (1) Method: piece-wise constant model (2) Population: East and West Germans of the cohorts 1961-1980, who were childless in the } \\
\text { beginning of the year } 1991 \text { (3) Cases were left-censored in the year } 1991 \text { (4) Date of birth was backdated by nine months (5) Several } \\
\text { flag variables were added to the regressions: for activity status missing, for missing information on educational attainment and for } \\
\text { missing information on the month of birth (6) } * *: p \leq 0.01 * *: 0.01 \leq p \leq 0.05 *: 0.05 \leq p \leq 0.10 \text { (7) Source: SOEP }\end{array}$} \\
\hline
\end{tabular}


Table 3: First Birth Risks in East and West Germany after Unification (Model III)

\begin{tabular}{|c|c|c|c|c|c|c|c|c|}
\hline & \multicolumn{2}{|r|}{ East Germans } & \multicolumn{3}{|c|}{ East Germans } & \multicolumn{3}{|c|}{ West Germans } \\
\hline & $\mathrm{b}$ & $\exp (b)$ & $\mathrm{b}$ & $\exp (b)$ & $\mathrm{t}$ & $\mathrm{b}$ & $\exp (b)$ & $\mathrm{t}$ \\
\hline \multicolumn{9}{|c|}{ Baseline (age) } \\
\hline $15-20$ & -4.13 & 0.016 & -4.13 & 0.016 & & -4.82 & 0.008 & \\
\hline $20-24$ & -3.18 & 0.042 & -3.19 & 0.041 & & -3.51 & 0.030 & \\
\hline $24-28$ & -3.00 & 0.050 & -3.00 & 0.050 & & -3.27 & 0.038 & \\
\hline $28-38$ & -3.03 & 0.048 & -3.03 & 0.048 & & -3.25 & 0.039 & \\
\hline
\end{tabular}

\section{Activity Status}

In education

Part-time employment

Full-time employment

Unemployment

$\begin{array}{rrl}-0.65 & 0.52 & -4.20 * * * \\ 0.10 & 1.10 & 0.43 \\ 0 & 1 & \\ 0.62 & 1.86 & 4.03 * * * \\ & & \\ 0.99 & 2.68 & 8.82 * * *\end{array}$

$\begin{array}{rrc}-0.65 & 0.52 & -4.19 * * * \\ 0.10 & 1.10 & 0.44 \\ 0 & 1 & \\ 0.62 & 1.85 & 4.00 * * * \\ & & \\ 0.97 & 2.64 & 8.47 * * *\end{array}$

$\begin{array}{lll}-0.61 & 0.54 & -3.14 * * *\end{array}$

$\begin{array}{lll}0.12 & 1.13 & 0.44\end{array}$

$\begin{array}{ll}0 & 1\end{array}$

$0.63 \quad 1.88 \quad 3.11 * * *$

Conjugal Union

$\begin{array}{rrr}0.11 & 1.12 & 0.47 \\ 0 & 1 & \\ 0.19 & 1.20 & 0.69 \\ -0.17 & 0.84 & -0.69\end{array}$

$\begin{array}{rrr}0.13 & 1.13 & 0.52 \\ 0 & 1 & \\ 0.16 & 1.17 & 0.58 \\ -0.13 & 0.88 & -0.52\end{array}$

0.03

$1.03 \quad 0.12$

In Education

Full-time employment

Non-regular employment

$\begin{array}{lll}-0.17 & 0.84 & -0.69\end{array}$

$-0.13 \quad 0.88$

$-0.52$

$-0.36$

1

Unemployment

$-$

$0.09 \quad 1.09$

0.58

$0.96-0.11$

Change of Job (Partner)

Note: (1) Method: piece-wise constant model (2) Population: East and West Germans of the cohorts 1961-1980, who were childless in the
beginning of the year 1991 (3) Cases were left-censored in the year 1991 (4) Date of birth was backdated by nine months (5) Several
flag variables were added to the regressions: for missing information on the month of birth, for missing information on educational
attainment, for missing information for conjugal union, for missing information on activity status of partner and for missing
information on change of job of partner (6) $* * *: p \leq 0.01 * *: 0.01 \leq p \leq 0.05^{*}: 0.05 \leq p \leq 0.10$ (7) Source: SOEP 
Figure 1: Birth Rates in East and West Germany

Panel 1: Live Births in East Germany (in 1,000)

Panel 2: TFR in East and West Germany
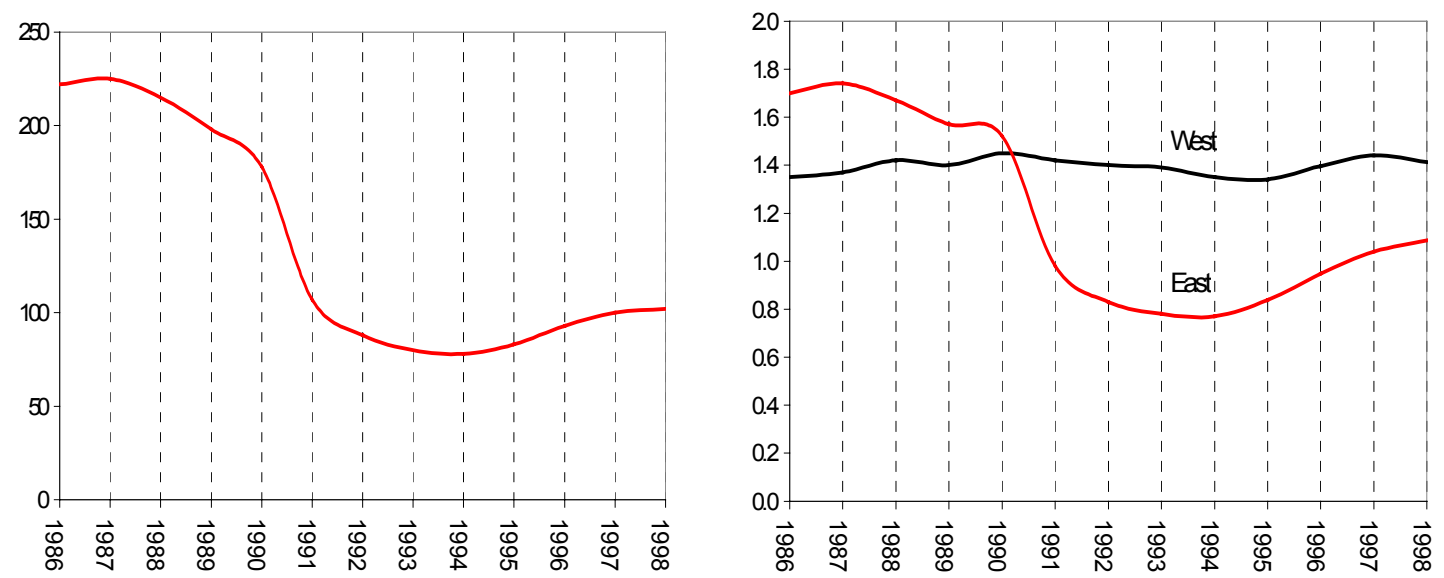

Source: Statistisches Bundesamt (1999)

Figure 2: Unemployment Rates 1991-1999

Panel 1: Male Unemployment Rates

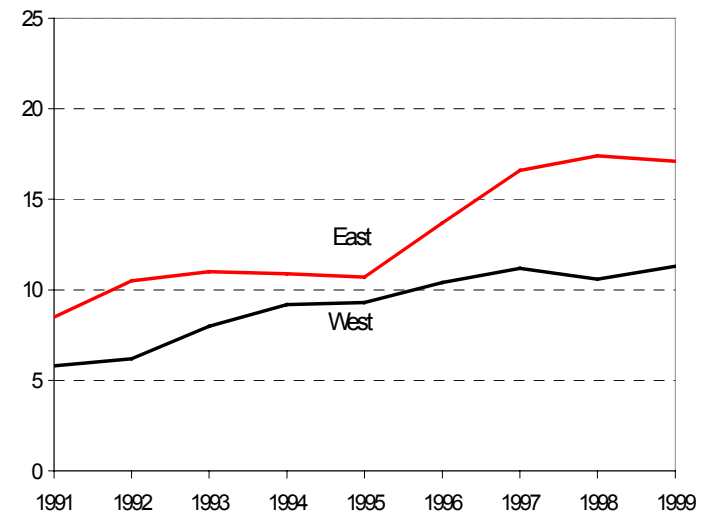

Panel 2: Female Unemployment Rates

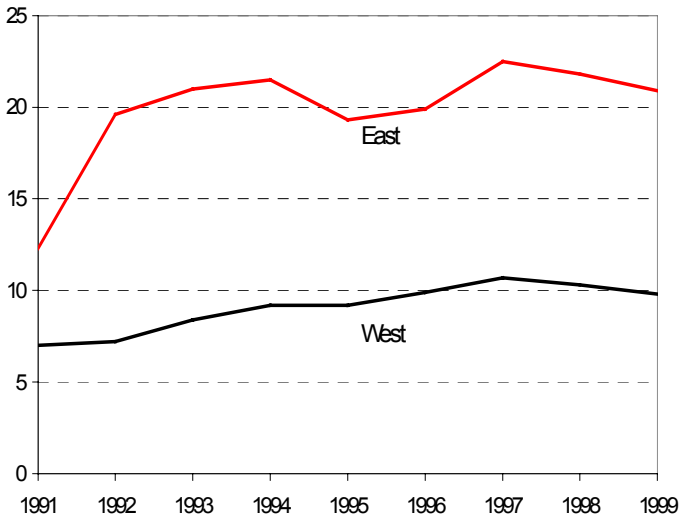

Source: Bundesanstalt für Arbeit (2000) 
Figure 3:Transition to First Birth by Birth Cohorts

Panel 1: Cohorts 1955-60 (Censoring: 1991)

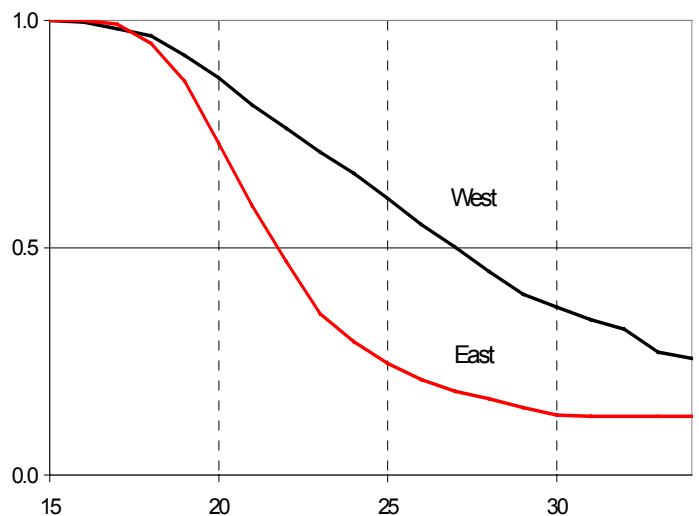

Panel 2: East German Cohorts 1955-1980

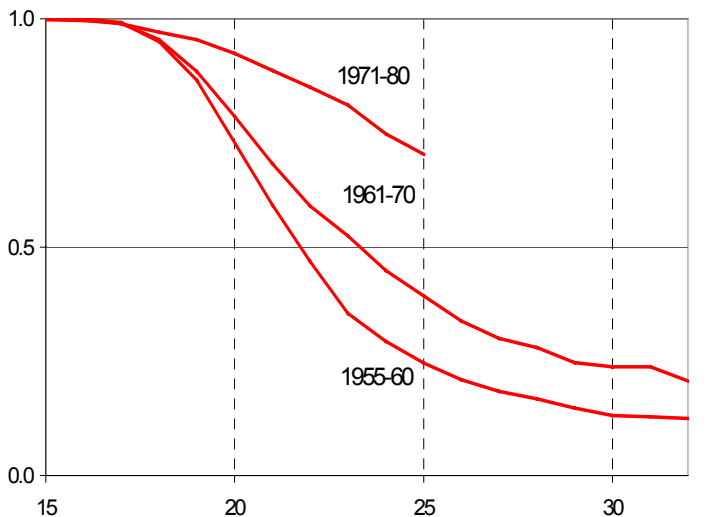

Note: (1) Method: Kaplan-Meier survival curves (2) Time scale: age of woman (3) Source: SOEP

Figure 4: Transition to First Birth, (only women, who are childless in 1991)

Panel 1: Cohorts 1971-80

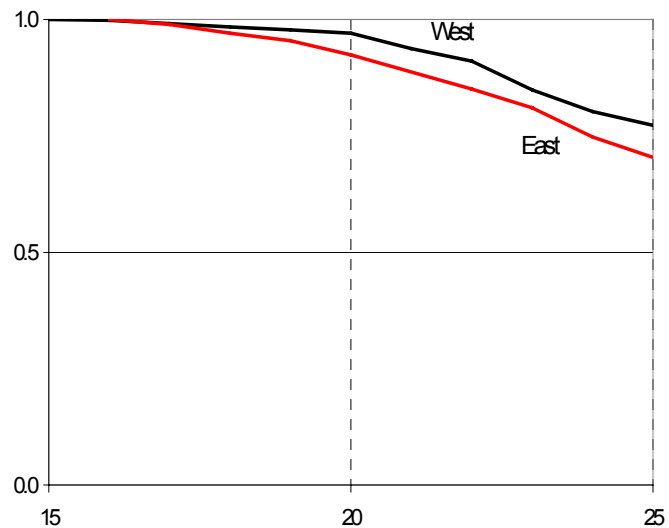

Panel 2: Cohorts 1961-70

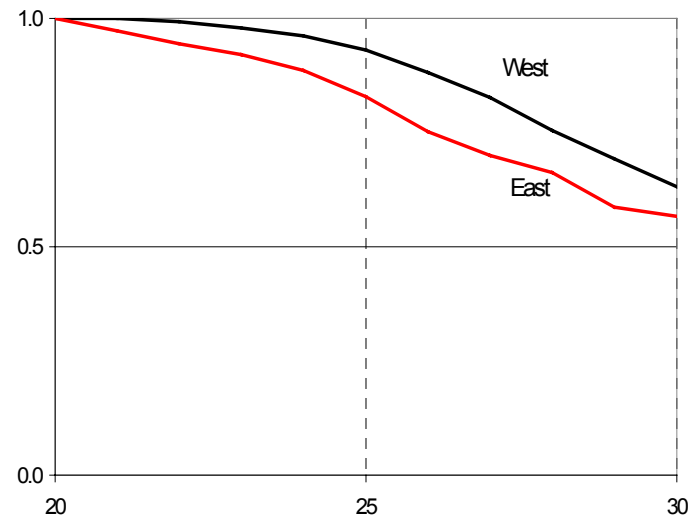

Note: (1) Method: Kaplan-Meier survival curves (2) Time scale: age of woman (3) Populations: only respondents, who were childless in the beginning of the year 1991 (4) The survival curves are tested for equality using a Peto-Test (see e.g., Kleinbaum 1996: 65). In both panels, they are significantly different from one another on the 5 percent level (5) Source: SOEP 